\title{
Fc-receptor mediated clearance of immune complex-like material in Crohn's disease patients with elevated liver enzymes
}

\author{
G.Y. Minuk, MD, FRCP(C), C. BOHME, BSC, N.B. Hershfield, MD, FRCP(C), FACP, W. Y. LeE, PHD, \\ K.L. MACCANNELL, MD, FRCP(C), L.M. PRICE, MD, FRCP(C), \\ E.A. SHAFFER, MD, FRCP(C), L.R. SUTHERLAND, MD, FRCP(C)
}

\begin{abstract}
The reticuloendothelial system of patients with ulcerative colitis and associated liver disease is impaired in its ability to clear immune complex-like material from the systemic circulation. The purpose of the present study was to determine whether patients with Crohn's disease and associated liver enzyme abnormalities manifest the same reticuloendothelial system clearance defect. Autologous red cells were radiolabelled with ${ }^{51} \mathrm{Cr}$ and sensitized with anti-Rh(D) immunoglobulin $\mathrm{G}$ in vitro. After intravenous infusion of the labelled antibody-coated red cells, the radioactivity content of timed blood specimens was measured. The time required by the reticuloendothelial system to clear one-half the labelled cells from the circulation $(T 1 / 2)$ was then determined. The $T 1 / 2$ clearance times in nine Crohn's disease patients with elevated serum liver enzyme levels $(59.7 \pm 6.4$ mins, mean \pm SEM) was similar to that of nine Crohn's disease patients with normal liver enzyme levels (50.7 \pm 4.6 mins), 12 chronic liver disease control patients ( $63.4 \pm 6.3$ mins) and 12 healthy volunteers $(49.1 \pm 3.1$ mins) $(\mathrm{P}>0.05)$. The results of this study indicate that the reticuloendothelial system clearance defect described in patients with ulcerative colitis and associated liver disease is not present in patients with Crohn's disease and associated mild liver enzyme abnormalities. Can J Gastroenterol 1987;1(1):18-22
\end{abstract}

Key Words: Crohn's disease, Fc-receptor, Immune complexes, Liver disease, Reticuloendothelial system, Sclerosing cholangitis

Correspondence: Dr G.Y. Minuk, Assistant Professor, Department of Medicine, University of Calgary, Health Science Centre, 3330 Hospital Drive NW. Calgary, Alberta T2N 4N1

Received for publication June 4, 1987. Accepted July 29, 1987
A THOUGH HEPATOBILIARY DISEASE is a well recognized complication of both idiopathic ulcerative colitis and Crohn's disease, important differences exist in the incidence and type of liver disease associated with these two disorders (1-3). In particular, biochemical evidence of chronic liver disease is found in 8 to $50 \%$ of ulcerative colitis patients (4-7), while only $4 \%$ of Crohn's disease patients have persistent elevations of their serum liver enzyme levels $(1,3)$. Moreover, in ulcerative colitis, primary sclerosing cholangitis is the most common associated hepatic disorder (2,8-10), while in Crohn's disease, hepatic steatosis and granulomas are more often found (11). These findings suggest that the hepatobiliary complications of ulcerative colitis and Crohn's disease may be caused by different pathogenetic mechanisms.

Recently, it was reported that patients with ulcerative colitis and chronic liver 
disease have an impaired ability to clear immune complex-like material from the systemic circulation (12). This defect did not exist in patients with ulcerative colitis alone or patients with clearly defined liver disease of other etiologies. On the basis of these and other investigators findings $(13,14)$, it was proposed that immune complexes could play an important role in the pathogenesis of the liver disease associated ulcerative colitis. The present study aimed to determine if the same clearance defect exists in Crohn's disease patients with or without associated liver disease.

\section{MATERIALS AND METHODS}

Study populations: Four groups of individuals were studied: 12 healthy volunteers; nine patients with Crohn's disease only, ie, normal liver enzyme levels on two separate occasions at least one month apart; nine patients with Crohn's disease and persistent elevations of liver enzyme levels (aminotransferases 2 or more times normal or alkaline phosphatase and gamma glutamyltransferase 1.5 or more times normal) on two separate occasions at least one month apart; and 12 patients with various other forms of liver disease including alcoholic liver disease $(\mathrm{n}=6)$, chronic viral hepatitis $(\mathrm{n}=2)$, common bile duct stricture $(\mathrm{n}=1)$, choledochal and intrahepatic lithiasis $(\mathrm{n}=1)$, hemochromatosis $(\mathrm{n}=$ 1) and drug-induced cholestatic jaundice $(n=1)$. Crohn's disease patients with or without liver enzyme abnormalities were identified by retrospective chart review.

A careful history, physical examination and the appropriate laboratory tests were performed on all patients with Crohn's and liver disease to exclude readily identifiable causes of liver disease, including alcohol, drugs, viral infection and metabolic disorders. Because liver enzyme levels were only mildly elevated, invasive procedures such as percutaneous liver biopsy or endoscopic retrograde cholangiography were not performed and thus the exact nature of the liver disease in these patients was unknown.

Three of nine Crohn's and liver disease patients had complaints consistent with extraintestinal Crohn's disease (arthritis in all three), as compared to four of nine patients with Crohn's dis-

TABLE 1

Patient population characteristics

\begin{tabular}{|c|c|c|c|c|c|c|}
\hline $\begin{array}{l}\text { Study group } \\
\text { (number of patients) }\end{array}$ & Age & $\begin{array}{l}\text { Sex } \\
M: F\end{array}$ & $\begin{array}{c}\text { AST } \\
(0-40 \mathrm{iu} / \mathrm{L})^{*}\end{array}$ & $\begin{array}{c}\text { ALI } \\
(0-36 \mathrm{iu} / \mathrm{L})\end{array}$ & $\begin{array}{c}\text { AP } \\
(30-115 \mathrm{iu} / \mathrm{L})\end{array}$ & $\begin{array}{l}\text { GGT } \\
(85 \mathrm{iu} / \mathrm{L})\end{array}$ \\
\hline Healthy volunteers (12) & $27 \pm 3.3+$ & - & & & & \\
\hline & & & & & & \\
\hline $\begin{array}{l}\text { Crohn's disease and } \\
\text { chronic liver } \\
\text { disease (9) }\end{array}$ & 20.0 & $2: 7$ & $36.7 \pm 5.9$ & 4 & 4 & 111. \\
\hline Chronic liver disease (12) & $45.5+3.8$ & $5: 7$ & $102.6+12.0$ & $78.7 \pm 8.9$ & $372.1 \pm 20.8$ & $262.0 \pm 17.3$ \\
\hline
\end{tabular}

- Normal levels: + Means \pm SEM; AST Aspartate aminotransferase: ALT Alanine aminotransferase: GGT Gamma glutamyltransferase: AP Alkaline phosphatase

ease alone (arthritis alone in two and arthritis plus iritis in two). Five of the nine Crohn's and liver disease patients were taking oral corticosteroids ( 5 to $30 \mathrm{mg}$ prednisone equivalents), compared to three of nine with Crohn's disease alone $(5$ to 20 prednisone equivalents). One patient in each group was also taking metronidazole.

Written, informed consent was obtained from all study participants. The study was approved by the University of Calgary and Foothills Hospital Ethics Committee and Radiation Safety Committee at the University of Calgary.

Clinical and laboratory investigations: All participants had blood drawn for the following laboratory tests: serum aspartate aminotransferase; alanine aminotransferase; alkaline phosphatase; and gamma glutamyltransferase. In addition. sera were tested for $\lg A, \lg G$ and $\lg M$ levels as well as serum $C_{3}$ and $C_{4}$ levels. These investigations were performed by hospital clinical laboratories using standard laboratory techniques. Sera were screened for immune complex-like activity by solid phase enzyme-linked immunoassays for both $\lg G$ and $\operatorname{lgM}$ complexes (15).

Immune complex clearance by the reticuloendothelial system: Erythrocyte clearance studies were carried out on all $R h(D)$ positive patients as previously described $(16,17)$. In brief, autologous erythrocytes were isolated from whole blood, washed three times in ice cold physiologic saline and resuspended to a concentration adjusted photometrically to $6.6 \times 10^{8}$ cells $/ \mathrm{mL}$. The cells were labelled with sterile ${ }^{51} \mathrm{Cr}\left(\mathrm{Na}_{2}{ }^{51} \mathrm{CrO} 10\right.$ $\mu \mathrm{Ci} / \mathrm{mL}$, Amersham-Searle Corporation, Arlington Heights, II), washed four times in physiologic saline, then resuspended to a concentration of $3.3 \times 10^{8}$ cells $/ \mathrm{mL}$. An aliquot of the cells was then sensitized by the addition of $\operatorname{IgG}$ anti$\mathrm{Rh}$ (D) $(0.4 \mu \mathrm{g} / \mathrm{mL}$, WinRho, Winnipeg. Manitoba) sufficient, according to preliminary experiments, to result in the binding of approximately 3000 molecules of IgG per erythrocyte. The same lot of anti-Rh(D), containing noncomplement fixing IgG, was used for all experiments. The erythrocyte- $\operatorname{lgG}$ mixture was incubated at $37^{\circ} \mathrm{C}$ for $30 \mathrm{mins}$, following which the $\lg \mathrm{G}$ sensitized ${ }^{51} \mathrm{Cr}$ labelled erythrocytes were washed twice and resuspended in physiologic saline. An aliquot of cells (containing approximately 250,000 counts $/ \mathrm{min}$ ) was then injected through an antecubital vein, and erythrocyte survival calculated from the radioactivity in blood samples obtained at $5,10,30,60,90$ and 120 mins (AUC Trapezoidal Rule, Ti 59), as recommended by the International Committee for Standardization in Haematology (18). In no case was a clearance study followed by any untoward effect.

Definitions and statistical techniques: The half-life of the radiochromated cells is the time at which $50 \%$ of the labelled cells has been removed from the circulation. A Student's test and Fisher's exact test were used for determining differences between groups of patients and controls. Only $P$ values less than 0.05 were considered significant.

\section{RESULTS}

Table 1 provides the results of age, sex and liver enzyme tests for the four study groups. Liver disease patients had more severe liver disease than Crohn's and liver disease patients as manifest by the 


\section{TABLE 2}

Immunologic laboratory results

\begin{tabular}{|c|c|c|c|c|c|c|c|}
\hline \multirow{2}{*}{$\begin{array}{l}\text { Study group (number } \\
\text { of patients) }\end{array}$} & \multicolumn{3}{|c|}{ Immunoglobulin determinations $(\mathrm{g} / \mathrm{L})$} & \multicolumn{2}{|c|}{ Complement levels (g/L) } & \multicolumn{2}{|c|}{ Immune complex levels (OD units) } \\
\hline & $\begin{array}{c}\lg A \\
(0.7-3.12) \dagger\end{array}$ & $\begin{array}{c}\lg G \\
(6.4-13.5)\end{array}$ & $\begin{array}{c}\lg M \\
(0.52-3.52)\end{array}$ & $\begin{array}{c}\mathrm{C}_{3} \\
(0.83-1.77)\end{array}$ & $\begin{array}{c}\mathrm{C}_{4} \\
(0.15-0.45)\end{array}$ & $\underset{1 \mathrm{lg} G}{(<0.2)}$ & $\begin{array}{l}\lg M \\
(0.2)\end{array}$ \\
\hline Crohn's disease (9) & $2.37 \pm 0.96$ & $10.2 \pm 1.2$ & $1.67 \pm 0.80$ & $1.32 \pm 0.39$ & $0.22 \pm 0.28$ & $0.09 \pm 0.03$ & $0.05 \pm 0.02$ \\
\hline Chronic liver disease (12) & $4.01 \pm 1.23 \cdots$ & $14.7 \pm 2.4^{\circ}$ & $3.66 \pm 2.16$ & $1.25 \pm 0.67$ & $0.19 \pm 0.24$ & $0.20 \pm 0.04$ & $0.11 \pm 0.05$ \\
\hline
\end{tabular}

$\cdot P<0.05 ; \cdots p<0.01,+$ Normal levels: $\neq$ Mean \pm SEM: OD Optical density

extent of liver enzyme abnormalities in the former group.

The results of serum immunoglobulin determinations, $\mathrm{C}_{3}$ and $\mathrm{C}_{4}$ levels and immune complex-like activity are shown in Table 2. Compared to healthy volunteers, mean serum IgA, IgG and IgM levels were normal in Crohn's disease and Crohn's and liver disease patients but $\lg \mathrm{A}$ and $\lg G$ levels were significantly elevated $(\mathrm{P}<0.01$ and $\mathrm{P}<0.05$, respectively) in liver disease controls. Mean serum $\mathrm{C}_{3}$ and $\mathrm{C}_{4}$ levels were similar in all four study groups. Immune complex-like ac- tivity was higher in liver disease patients when compared to Crohn's disease $(\mathrm{P}<0.05)$ and Crohn's and liver disease patients $(\mathrm{P}<0.05)$ but not statistically different from healthy volunteers $(\mathrm{P}=0.06)$.

The results of IgG-tagged erythrocyte clearance studies are shown in Figure 1. All patients had normal clearance curves when compared to healthy controls.

Figure 2 provides the results of computer generated half-lives in individual patients. The mean \pm SEM half-life for healthy volunteers was $49.1 \pm 3.1 \mathrm{mins}$, as compared to $50.7 \pm 4.6$ mins for
Crohn's disease patients, $59.7 \pm 6.4$ mins for Crohn's and liver disease patients, and $63.4 \pm 6.3 \mathrm{mins}$ for liver disease patients. Employing 69 mins as the upper limit of normal ( 2 standard deviations from the mean for healthy volunteers), two of nine Crohn's disease patients, three of nine Crohn's and liver disease patients and three of 12 liver disease patients were considered to have prolonged clearance times. These differences were not statistically significant $(P>0.05$. Fisher's exact test).

Clearance times were normal in two

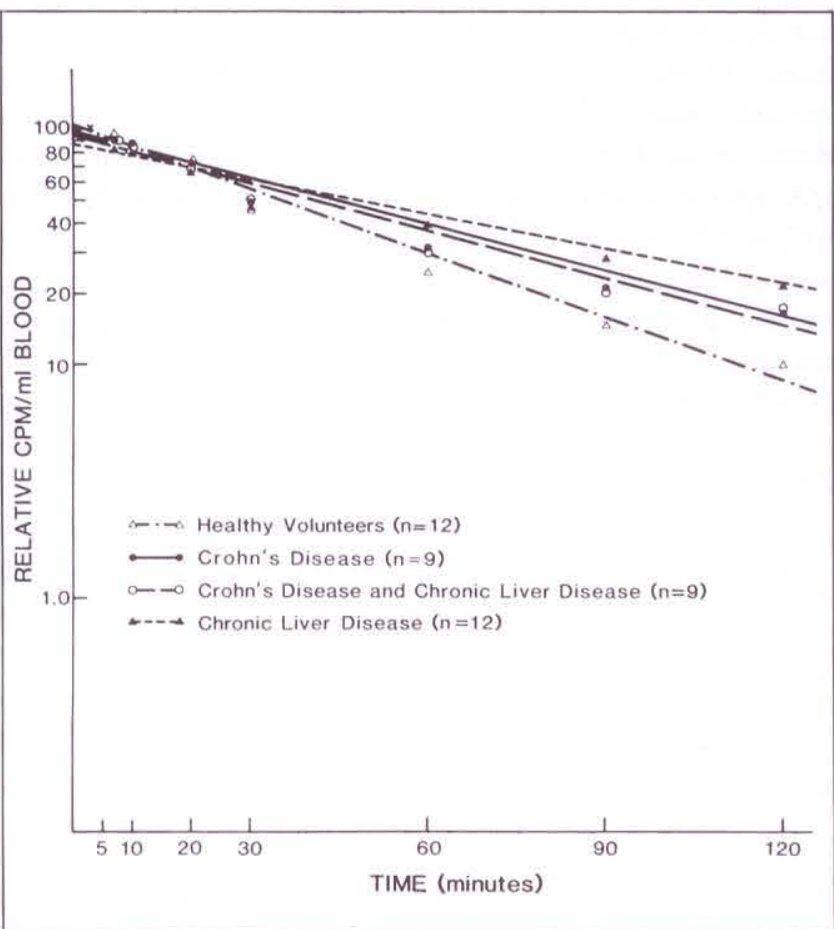

Figure 1) Clearance of IgG-sensitized radiochromated autologous erythrocytes from the circulation. Radioactivity per unit volume of blood is expressed as a percentage of the hypothetical value at zero time

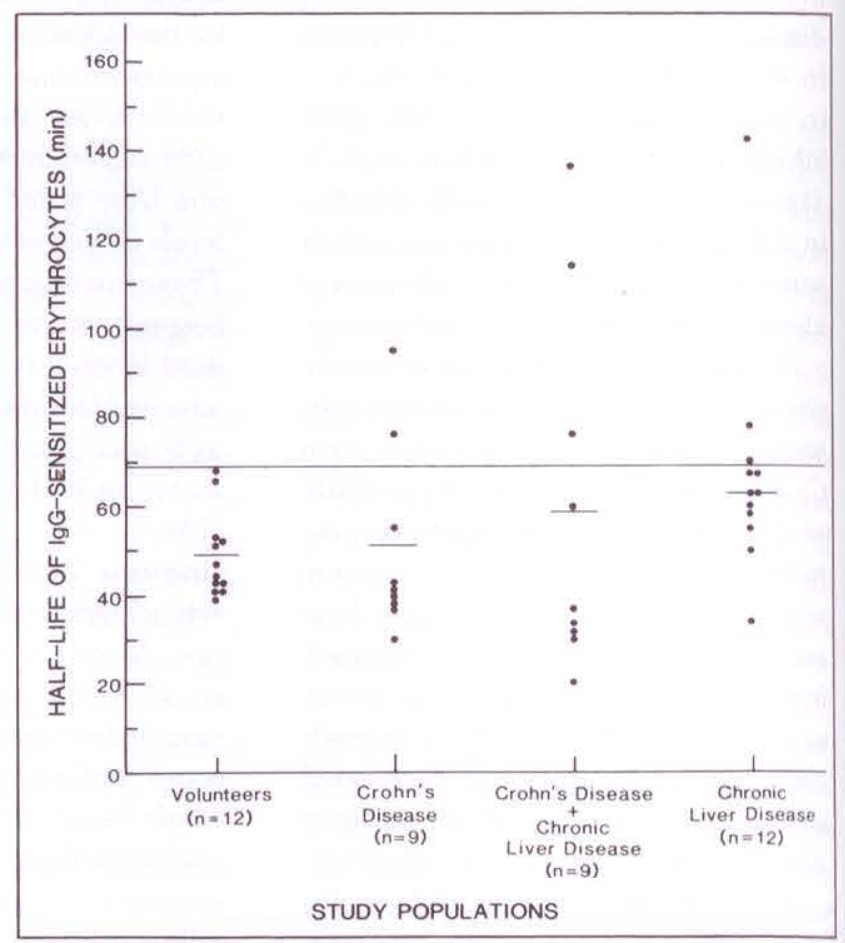

Figure 2) Clearance of IgG-sensitized radiochromated autologous erythrocytes from the circulation of individual patients. Horizontal bars represent mean values for each study group, the continuous horizontal line 2 standard deviations beyond the mean for volunteers 
of the three Crohn's and liver disease patients with arthritis and three of the four Crohn's disease patients with arthritis and/or iritis. There was no significant difference between mean clearance times for those taking corticosteroids versus those not on corticosteroids $(52.1 \pm 5.9$ versus $58.1 \pm 3.9$ mins, respectively).

\section{DISCUSSION}

In a previous study, it was shown that only $10 \%$ of ulcerative colitis patients with elevated liver enzyme levels had normal immune complex-like clearance function, as compared to greater than $80 \%$ of patients with ulcerative colitis alone and almost $90 \%$ of patients with various forms of chronic liver disease (12). The results of the present study indicate that the Fc-receptor-mediated clearance defect described in patients with ulcerative colitis and associated liver disease is not present in the majority of Crohn's and liver disease patients. It would appear that in addition to the differences in frequency and type of liver disease found in ulcerative colitis and Crohn's disease, there are significant differences th the prevalence of immunologic disturbances that could play a role in the pathogenesis of those hepatic complications.

The reticuloendothelial system's ability to clear immune complex-like material from the systemic circulation has been used previously to provide insight into the pathogenesis of diseases that are potentially immunologically mediated (19). Abnormal clearance function has now been documented in patients with systemic lupus erythematosus (20), mixed cryoglobulinemia (19). Sjogren's syndrome (21), mixed connective tissue disease (22), primary biliary cirrhosis (16). primary sclerosing cholangitis (23) and ulcerative colitis (12). In some of these disorders impaired clearance suggests disease extending beyond the primary target tissue. Thus, in mixed cryoglobulinemia prolonged clearance times indicate the presence of coexisting renal involvement (19); in Sjogren's syndrome, disease beyond the salivary glands (21); and hepatic involvement in ulcerative colitis (12). The results of the present study suggest that immune complex-like dearance function by the reticuloendo- thelial system is either normal or minimally prolonged in Crohn's disease patients whether their disease is confined to the bowel or associated with extraintestinal manifestations.

A direct comparison between the results of the present study and those of the earlier ulcerative colitis study (12) cannot be made for a number of reasons. First, as reflected in the more rapid clearance times for controls, a higher concentration of IgG antibodies per red blood cell was used in the present study. The higher antibody concentration was employed in order to increase the sensitivity of the assay (17). Secondly, the liver enzyme abnormalities in Crohn's and liver disease patients were significantly lower in the present study than in those with ulcerative colitis and liver disease. Indeed, the abnormalities in the former group were so slight that invasive investigations, which might have better defined their cause, were not performed. Nonetheless, the enzyme abnormalities observed in Crohn's and liver disease patients were persistent and not readily attributable to other causes. Finally, a larger percentage of Crohn's and liver disease patients $(56 \%)$ than ulcerative colitis and liver disease patients $(20 \%)$ were taking corticosteroids for control of their bowel disease. This may be relevant in that, in experimental animals, corticosteroids have been shown to alter immune complex clearance times by the reticuloendothelial system $(17,24)$. It should be noted, however, that no difference was found in clearance times between Crohn's disease patients receiving corticosteroids versus those that were not.

The interpretation and significance of serum immune complex-like activity in patients with immunologically mediated disease remains a controversial issue (25-30). In the present study, contrary to previous reports $(14,31-34)$, neither Crohn's and liver disease patients nor Crohn's disease patients without liver disease had elevated levels of immune complex-like activity in their serum. The reason for the discrepancy between the present authors' results and others' is unclear. The nonspecific nature of the assays presently employed for the detection of serum immune complexes would appear to be a major contributing factor $(28,29)$.

In conclusion, this study shows that the defect in the reticuloendothelial system's ability to clear specific immune complex-like material from the systemic circulation of patients with ulcerative colitis and liver disease is not present in Crohn's disease patients with mild but persistent liver enzyme abnormalities.

ACKNOWLEDGEMENTS: The authors acknowledge the support of the MSI Foundation of Alberta and the assistance of Ms B. Bishop for her prompt and accurate typing of the manuscript.

\section{REFERENCES}

1. Greenstein A, Janowitz A, Sachar D The extra-intestinal complications of Crohn's disease and ulcerative colitis: A study of 700 patients. Medicine 1976:55:401-12.

2. Shepherd HA, Selby WS, Chapman RWG, et al. Ulcerative colitis and persistent liver dysfunction. QJ Med 1983;208:503-13

3. Rankin GB, Watts HD, Melynk CS, Kelley ML National cooperative Crohn's disease study: extraintestinal manifestations and perianal complications. Gastroenterology 1979;77:914-20.

4. Dew MI. Thompson H, Allen RN. The spectrum of hepatic dysfunction in inflammatory bowel disease. QJ Med 1979:189:113-35

5. Perrett AD. Higgins G, Johnston $\mathrm{HH}$. Massarella GR. Truelove SC, Wright R. The liver in ulcerative colitis. QJ Med 1971:40:211-38.

6. Pollard HM, Block M. The association of hepatic dysfunction with chronic ulcerative colitis. Arch Intern Med 1948:82:159-74.

7. Vinnik IE, Kern F. Liver diseases in ulcerative colitis. Arch Intern Med 1963:112:41-9.

8. Sivak MV Jr, Farmer RG, Lalli AF. Sclerosing cholangitis: its increasing frequency of recognition and association with inflammatory bowel disease. J Clin Gastroenterol 1981:3:261-6.

9. Schrumpf E, Elgjo K. Fausa O, Gjone E, Kolmannskog F, Ritland S. Sclerosing cholangitis in ulcerative colitis. Scand ] Gastroenterol 1980; 15:689-97.

10. Eade MN. Liver disease in ulcerative colitis. I. Analysis of operative liver biopsy in 138 consecutive cases having colectomy. Ann Intern Med 1970; 72:475-87

11. Holdstock G, Millward-Sadler GH. Wright R. Hepatic changes in systemic disease. In: Wright R, Alberti KGMM, 
Karran S, Millward-Sadler GH, eds. Liver and Biliary Disease. Philadelphia: WB Saunders Co, 1979:869.

12. Minuk GY, Hershfield NB, Lee WY, et al. Reticuloendothelial system Fc receptor mediated clearance of IgG tagged erythrocytes from the circulation of patients with idiopathic ulcerative colitis and chronic liver disease. Hepatology 1986;6:1-5.

13. Bodenheimer HC, LaRusso NF, Thayer WR, Charland C, Staples PJ, Ludwig J. Elevated circulating immune complexes in primary sclerosing cholangitis. Hepatology 1983;3:150-4.

14. Hodgson HJF, Potter BJ, Jewell DP. Immune complexes in ulcerative colitis and Crohn's disease. Clin Exp Immunol 1977;29:187-96.

15. Ziola B, Salmi A. Penttinen K. Porcine Clq and the solid-phase immuno-assay of human immune complexes. J Immunol Methods 1982;49:247-60.

16. Jaffe CJ, Vierling JM, Jones EA, Lawley T], Frank MM. Receptor specific clearance by the reticuloendothelial system in chronic liver disease: demonstration of defective $\mathrm{C} 3 \mathrm{~b}$-specific clearance in primary biliary cirrhosis. J Clin Invest 1978;62:1069-77.

17. Frank MM, Schreiber AD, Atkinson JP, Jaffe CJ. Pathophysiology of immune hemolytic anemia. Ann Intern Med 1977;87:210-22.

18. Report by the International Committee for Standardization in Hematology Panel. 1971. Recommended methods for radioisotope red cell survial studies. $\mathrm{Br}$ J Haematol 1971;21:241-50.
19. Frank MM, Lawley TJ, Hamburger MI, Brown EJ. Immunoglobulin G Fc receptor-mediated clearance in autoimmune diseases. Ann Intern Med 1983;98:206-18.

20. Frank MM, Hamburger MI, Lawley TJ, Kimberly RP, Poltz PH. Defective reticuloendothelial system $\mathrm{Fc}$ receptor function in systemic lupus erythematosus. N Engl J Med 1979;300:518-23.

21. Hamburger MI, Moutsopoulos HM, Lawley TJ, Frank MM. Sjogren's syndrome: a defect in reticuloendothelial system Fc-receptor specific clearance. Ann Intern Med 1979;91:534-8.

22. Hamburger MI, Moutsopoulos HM, Lawley T], Sharp GC, Frank MM. Reticuloendothelial system Fc receptor function in mixed connective tissue disease. Arthritis Rheum 1979;22:618. (abst)

23. Minuk GY, Angus M, Brickman CM, et al. Abnormal clearance of immune complexes from the circulation of patients with primary sclerosing cholangitis. Gastroenterology 1985;88: 166-70.

24. Atkinson JP, Schreiber AS, Frank MM. Effects of corticosteroids and splenectomy on the immune clearance and destruction of erythrocytes. J Clin Invest 1973;52:1509-17.

25. Nielsen H, Hyltoft Petersen P, Svehag S-E. Circulating immune complexes in ulcerative colitis. II. Correlation with serum protein concentrations and complement conversion products. Clin Exp Immunol 1978;31:81-91.

26. Nielsen H, Binder V, Daugharty $\mathrm{H}$, et al.
Circulating immune complexes in ulcerative colitis. I. Correlation to disease activity. Clin Exp Immunol 1978;31:72-80

27. Soltis RD, Hasz D, Morris MJ, et al. Evidence against the presence of circulating immune complexes in chronic inflammatory bowel disease Gastroenterology 1979;76:1380-5.

28. Lawley TJ, James SP, Jones EA. Circulating immune complexes: their detection and potential significance in some hepatobiliary and intestinal diseases. Gastroenterology 1980; 78:626-41.

29. Goldberg MJ, Kaplan MM, Anderson $\mathrm{CL}$, et al. Evidence against an immune complex pathogenesis of primary biliary cirrhosis. Gastroenterology 1982;83: 677-83.

30. Kilpatrick DC, Weston J. Immune complex assays and their limitations. Med Lab Sciences 1985;42:178-85.

31. Doe WF, Booth CC, Brown DL. Evidence for complement-binding immune complexes in adult coeliac disease, Crohn's disease and ulcerative colitis. Lancet 1973;i:402-3.

32. Jewell DP, MacLennon ICM. Circulating immune complexes in inflammatory bowel disease. Clin Exp Immunol 1973;14:219-26.

33. Fiasse R, Lurhuma AZ, Masson PL, et al. The clinical significance of circulating immune complexes in Crohn's disease. Acta Gastroenterol Belg 1978;41:319-28.

34. Danis VA, Harries AD, Heatley RV. Antigen-antibody complexes in inflammatory bowel disease. Scand J Gastroenterol 1984:19:603-6. 


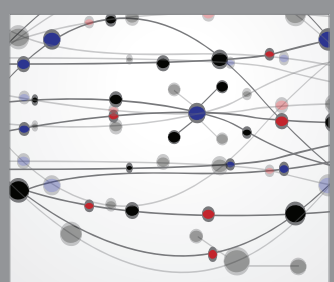

The Scientific World Journal
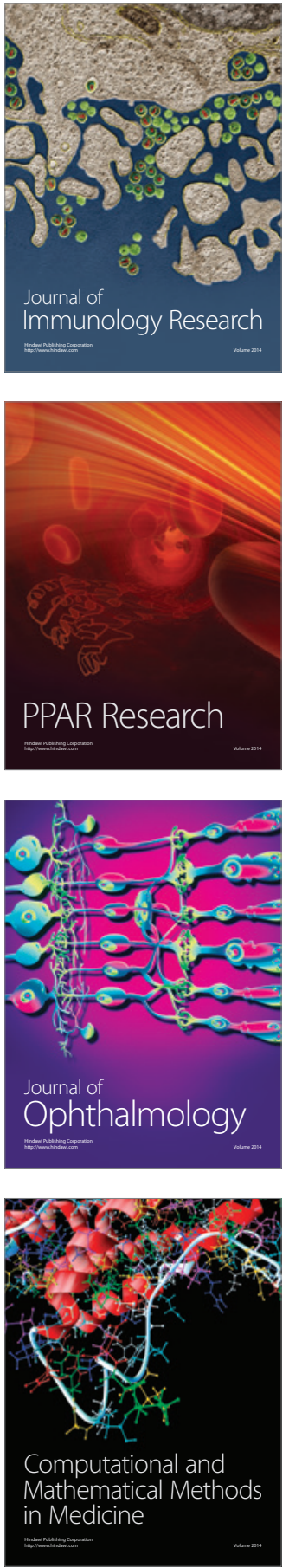

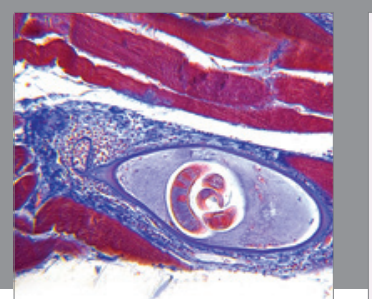

Gastroenterology Research and Practice

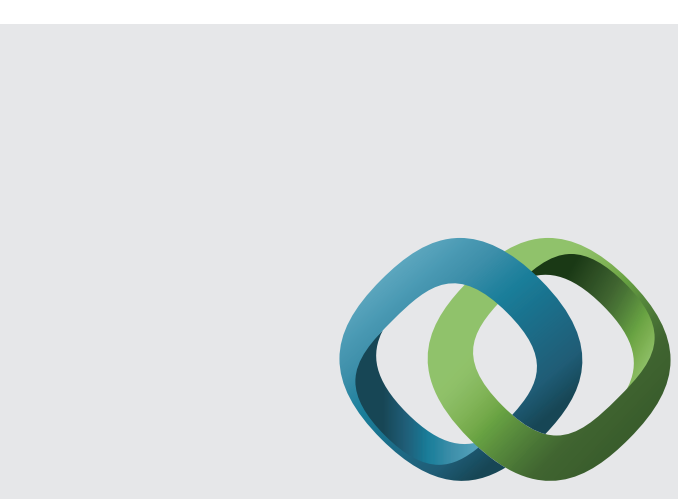

\section{Hindawi}

Submit your manuscripts at

http://www.hindawi.com
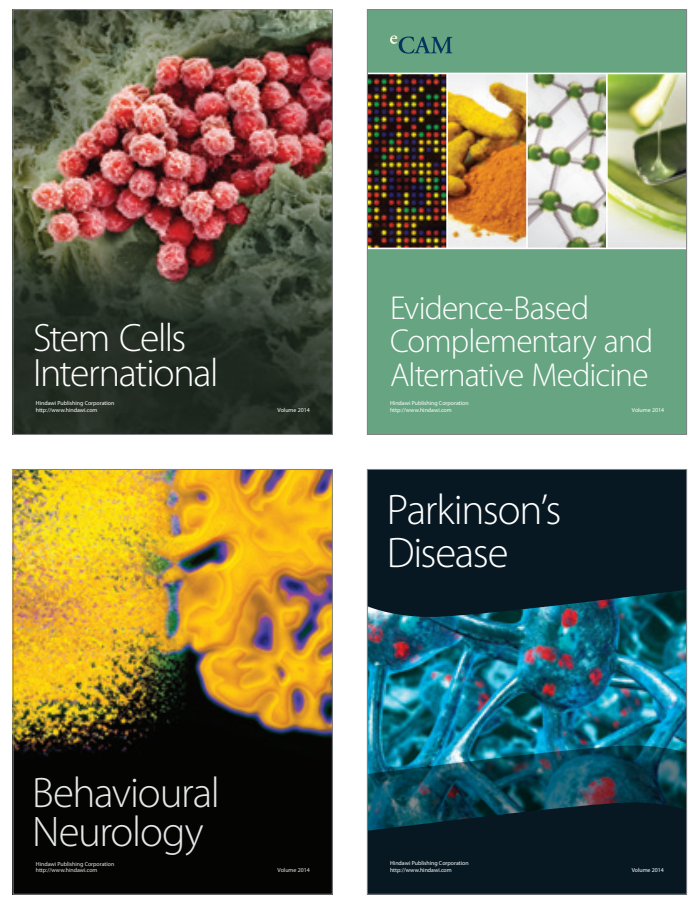
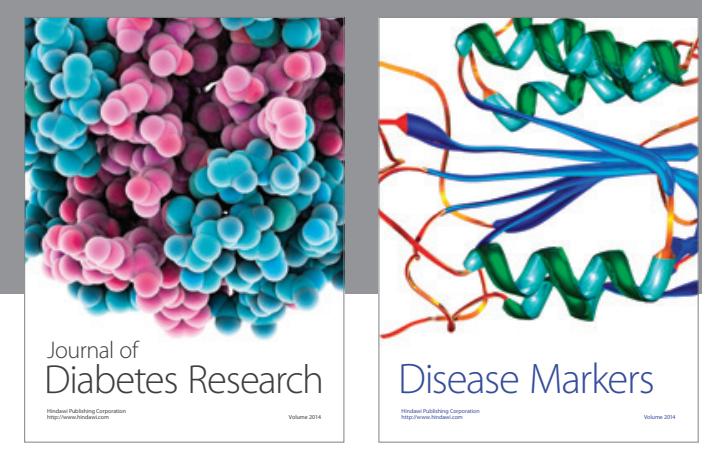

Disease Markers
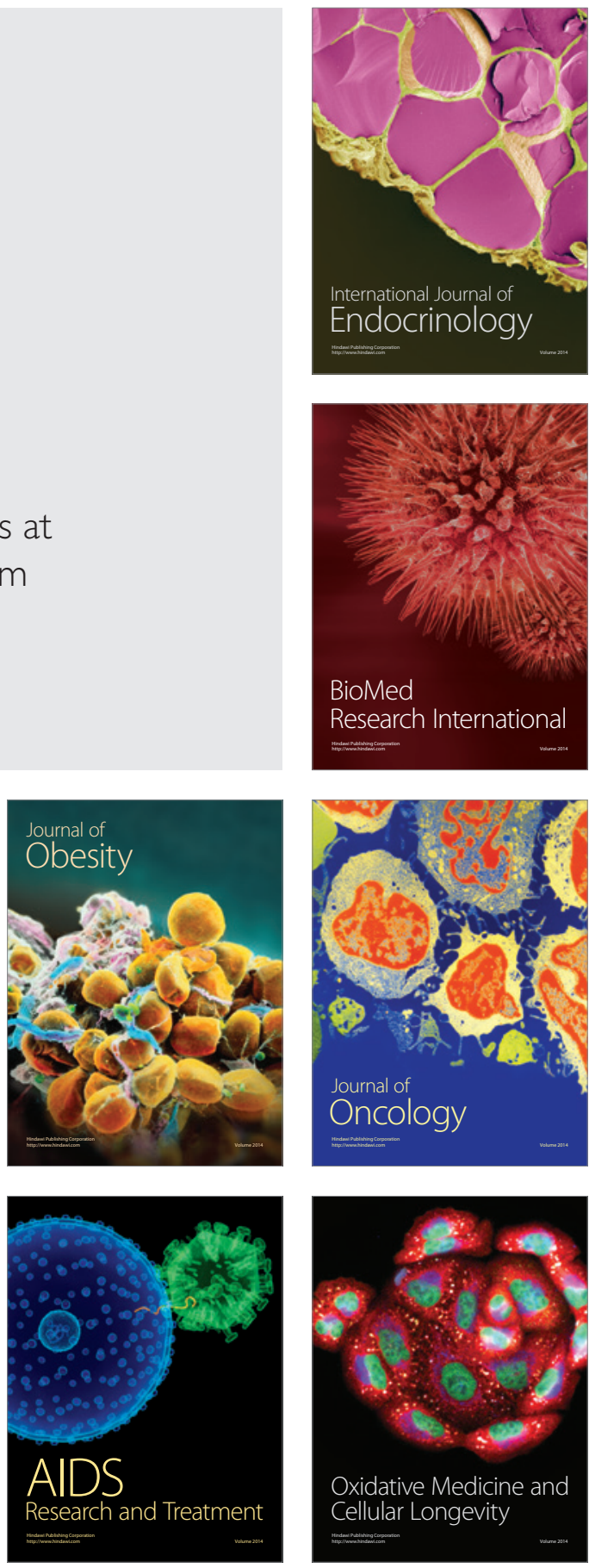